\section{Prevalence of sexually transmitted infections and bacterial vaginosis among lesbian women: systematic review and recommendations to improve care}

\author{
Prevalência de infecções sexualmente transmissíveis \\ e vaginose bacteriana em mulheres lésbicas: \\ revisão sistemática e recomendações para \\ melhoria do cuidado
}

\section{Prevalencia de infecciones sexualmente transmisibles y vaginosis bacteriana entre mujeres lesbianas: revisión sistemática y recomendaciones para mejorar el cuidado}

Maira Libertad Soligo Takemoto 1

Mariane de Oliveira Menezes 1 Carla Betina Andreucci Polido 2 Débora de Souza Santos 3

Valeria Marli Leonello 4 Claudia Garcia Magalhães 5 Jessica Fernandes Cirelli 6 Roxana Knobel 7

doi: $10.1590 / 0102-311 \times 00118118$

\begin{abstract}
Our aim was to systematically review data about the risk of sexually transmitted infections (STI) and bacterial vaginosis among lesbian women and to suggest strategies to improve prevention, diagnosis and treatment. A search strategy for lesbian, STI and bacterial vaginosis was applied to PubMed, LILACS and BDENF databases. Of 387 unique references retrieved, 22 fulfilled the inclusion criteria (cross-sectional studies reporting prevalence for 8 STIs/bacterial vaginosis and history of a STI). The most frequent infection reported was bacterial vaginosis, and none study reported data on hepatitis $B$. A wide range of prevalence was observed for most infections. In terms of risk factors, the number of sexual partners, the past or current smoking, a history of forced sex and sexual stigma seem to increase the risk of STI and bacterial vaginosis. The findings of this review are discussed considering guidelines directly addressing the LGBT community's health and relevant studies investigating both safe sexual practices and the intricate relationship between LGBT people and their care providers. A set of recommendations to improve preventive care for lesbian women is proposed. Affirming that little is known about the extent of STIs and bacterial vaginosis transmission in female-to-female sexual activities or about the risk factors for STI and bacterial vaginosis among lesbian women is reasonable. In fact, the overall quality of the studies was low or very low with significant uncertainty around their findings. However, we consider that the available knowledge indicates some paths to be followed by care providers and policy decision-makers to improve their actions towards better sexual health of lesbian women.
\end{abstract}

Sexually Transmitted Diseases; Bacterial Vaginosis; Female Homosexuality; Health Policy

\author{
Correspondence \\ M. L. S. Takemoto \\ Levatrice Cursos. \\ Av. Rio Branco 257, sala 901, Rio de Janeiro, RJ \\ 20040-009, Brasil. \\ mlibertad@gmail.com \\ 1 Levatrice Cursos, Rio de Janeiro, Brasil. \\ 2 Departamento de Medicina, Universidade Federal de \\ São Carlos, São Carlos, Brasil. \\ 3 Faculdade de Enfermagem, Universidade Estadual de \\ Campinas, Campinas, Brasil. \\ 4 Escola de Enfermagem, Universidade de São Paulo, \\ São Paulo, Brasil. \\ 5 Faculdade de Medicina de Botucatu, Universidade Estadual \\ Julio de Mesquita Filho, Botucatu, Brasil. \\ 6 Escola de Artes, Ciências e Humanidades, Universidade \\ de São Paulo, São Paulo, Brasil. \\ 7 Departamento de Ginecologia e Obstetrícia, Universidade \\ Federal de Santa Catarina, Florianópolis, Brasil.
}




\section{Introduction}

Poorer health outcomes and worse access to healthcare for sexual minorities are a well-established observation in the literature. Such disparities are consistently linked to discrimination, absence of respectful care, negative attitudes by care providers towards a disclosed sexual orientation or a gender nonconforming identity, privacy and confidentiality issues, lack of knowledge about the particularities of this population, and other factors that adversely affect effectiveness and trust in health system among the lesbian, gay, bisexual, and gender nonconforming (LGBT) community 1,2,3,4,5.

Trying to address this problem, the Brazilian Ministry of Health presented, in 2013, a National Policy for the Health of Lesbian, Gay, Bisexual, Trasvestites and Transsexual People. The Ministry of Health recognizes that discrimination and exclusion because of sexual orientation and gender identity adversely affects LGBT health 6. The 13th Brazilian National Health Conference, held in 2007, officially included both sexual orientation and gender identity as social determinants of health and determined a set of recommendations to address these aspects in health policies, including but not limited to: raising awareness about LGBT rights within the Brazilian Unified National Health System (SUS); establishing specific guidelines for the LGBT population (focusing on lesbians and transvestites); strengthening actions to prevent sexually transmitted infections (STIs); reinforcing the need for scientific research and technological innovation for this population 7 .

Historically, lesbian women's health and the specificities of female homosexuality have been considered invisible or even neglected. In the same direction, but for different reasons, this also occurs with female bisexuality. As an example, most of the discussions to prevent STIs in the LGBT population evolved from a larger debate about HIV and AIDS prevention among homosexual men. Due to a common understanding that lesbian women were a protected group for not engaging in "risk practices", they were not initially included in health actions to prevent STI/AIDS and are still underrepresented 6,8. Worldwide, studies have shown lesbian women have fewer pap smears, STI or HIV tests, or even gynecological consultations than their heterosexual or bisexual counterparts 1,9,10. Most of the Brazilian literature concerning lesbian women health consists of qualitative research, highlighting relevant barriers to access adequate health services and a perception of low or absent risk of STIs with a markedly low frequency of safe sex practices $2,11,12$.

Pinto et al. 13 conducted a survey with 145 Brazilian women who have sex with women (WSW) recruited from lesbian activist groups and from the LGBT Pride Parade in São Paulo, aiming at identifying STI prevalence and risk behaviors. The study did not report data on sexual orientation, but $36.6 \%$ had a male sexual partner (MSP) in the three previous years, while $23.4 \%$ had never had sex with men. Regarding safe sex practices, only $2.1 \%$ reported consistent use of condoms with female sexual partners (FSP), and the most frequent reason for not using was that they "didn't see a need for it" (42.2\%), followed by "trust in the partner" (17.3\%), and "unawareness that they should use it" (16.5\%). At the same time, $38.6 \%$ presented a history of STI and $44.1 \%$ reported having sex even when the partner is menstruating. Among those using sex toys, $45.8 \%$ shared the toy and $45.5 \%$ did not change the condom before sharing. These data reinforce that, despite of a self-perception of low risk and an infrequent use of safe sex practices, STI prevalence among WSW is worth exploring.

A literature review conducted by Brazilian researchers focusing on aspects of nursing care for lesbian women was not able to find any Brazilian published study, showing a lack of research about the topic 14. Qualitative or quantitative data on the knowledge and beliefs of health professionals about the care of this specific group and about effective educational interventions to improve their skills are also scarce 15. Thus, affirming that the healthcare related to STI prevention and general sexual health among lesbian women are poorly studied and undervalued by care providers, as well as underrepresented in health policies, is reasonable.

Focusing on the role of family physician care for lesbians, Knight \& Jarrett 16 discussed the obstacles for the optimal care of these women: lack of a welcoming environment, lack of communication, lack of high-quality research and evidence-based guidelines, among others. The authors also indicated that unprepared healthcare professionals may contribute to an unwelcoming environment, since they are unable to offer a dignified and high-quality care for lesbian women because of their lack of knowledge about the health issues affecting these women and hesitancy to broach sensitive topics of their sexual life. 
Considering this scenario, this study aimed to assess STI risks among lesbian women and discuss the former as essential data to inform care providers and decision-makers, focusing on suggesting strategies to improve STI prevention and screening and health education for safer sex practices. As previous studies reported a high prevalence of bacterial vaginosis (BV) among lesbian women and hypothesized a potential sexual transmission, BV was also included in the literature review, despite not being usually recognized as a STI 17,18,19. Previous studies have described a different risk profile for lesbian women in terms of STIs and risk behaviors compared with bisexual women 20,21,22,23. Also, despite the relative lack of data about the health of transgender people, anticipating that transgender women and men have particularities that would also lead to a different risk profile is possible. For these reasons, we decided to include only data about self-identified lesbian cisgender women in this review.

\section{Methods}

We used PRISMA statement to guide the report of this review 24 . The methods for search, selection, and data abstraction and analysis were predefined in a systematic review protocol registered with PROSPERO, under registration n. CRD42018092698 (http://www.crd.york.ac.uk/PROSPERO/).

\section{Eligibility criteria}

We searched for peer-reviewed studies published in full format, from January 1st, 1998 to March 31st, 2018 in English, Spanish, French, or Portuguese, investigating the prevalence or incidence of sexually transmitted infections or BV in populations including lesbian cisgender women. For the purposes of this review, lesbian cisgender women were defined as those referred as women in the studies, without any mention of being transgender, and whose classification was lesbian, as defined in each publication. This approach was adopted because assuring that the study samples were formed by people who identify themselves as cisgender women and lesbians was impossible. Thus, the review definition relies on the definitions from the studies included. If self-reported, sexual orientation was stated in the publication, this information was abstracted and described. In publications in which sexual orientation was not reported, data were deemed eligible only if clearly identified as being from women who have sex exclusively or predominantly with women (WSEW). Studies were excluded if the outcome variables of interest were not reported separately for this group of women (for example, if data was reported for "sexual minority women" or "women who have sex with women" without other specification of sexual orientation or sexual practices). If the sample had more than $90 \%$ of women described as lesbian or WSEW, the study was also included and this aspect was clearly described in the Results section. Studies investigating STI or BV risk among very specific populations (e.g., drug users, homeless people, sex workers, etc.) were excluded. In this article, the term "lesbian women" refers to cisgender women self-identified as lesbian, unless stated otherwise.

The definition of a STI or BV diagnosis was any diagnosis reported in the articles, regardless of being self-reported, medical record, clinical examination, or laboratory test results. Only observational studies (both cross-sectional and longitudinal) were deemed eligible. Letters to the editor, qualitative research, case reports, case series, and narrative literature reviews were excluded, but their reference lists were examined.

\section{Information sources and search strategy}

We searched for studies in the PubMed, LILACS, and BDENF databases (the last two using the Virtual Health Library search interface: http://pesquisa.bvsalud.org/portal/) using the search strategies described below:

- PubMed: (“Sexually Transmitted Diseases”[MeSH] OR "HIV”[MeSH] OR "Hepatitis B”[MeSH] OR "Hepatitis B, Chronic"[MeSH] OR “Hepatitis B virus”[MeSH] OR "Vaginosis, Bacterial”[MeSH] OR “Papillomaviridae”[MeSH] OR “Syphilis”[MeSH] OR “Sexually Transmitted Infections”[tw]) AND ("homosexuality, female"[MeSH] OR lesbian*[tw] OR "women who have sex with women" [tw]) 
AND (incidence[MeSH:noexp] OR incidence[Title/Abstract] OR prevalence[MeSH:no exp] OR prevalence[Title/Abstract] OR follow up studies[MeSH:noexp] OR "Epidemiologic Methods"[MeSH] OR risk*[Title/Abstract] OR risk*[MeSH:noexp] OR risk *[MeSH:noexp] OR "cohort studies"[MeSH] OR cohort*[Text Word] OR "Cross-Sectional Studies"[MeSH] OR "Case-Control Studies"[MeSH]).

- LILACS and BDENF: (mh:(homossexualidade feminina) OR tw:(lésbica) OR tw:("mulheres que fazem sexo com mulheres")) AND (mh:(Doenças sexualmente transmissíveis) OR tw:(DST) OR tw:(Hepatite) OR tw:(sífilis) OR tw:(HIV) OR tw:(HPV) OR tw:(vaginose)).

\section{Study selection}

A three-step selection process was conducted by two independent reviewers: reading of titles, abstracts, and full-text articles. The studies included in this step also had their reference lists screened for additional references. In cases of discordance regarding inclusion between the two reviewers, a third reviewer was consulted. Duplicates between databases were also excluded.

\section{Data collection and abstraction}

A data abstraction template was created by the review team, including the following information:

- Author, year, country and design;

- Population (sample size, proportion, or number of lesbian women);

- $\quad$ Participant characteristics (age, lesbian or WSEW definition, subgroups, etc.);

- Infection(s) investigated and method of diagnosis;

- Incidence or prevalence data;

- $\quad$ Risk factors assessed.

\section{Analysis}

The pooling of results by meta-analysis was not planned primarily because of differences in the infections reported, in how each infection was defined, and mainly in characteristics of the samples. After the study selection process, this initial approach was deemed adequate by the authors, once the number of studies assessing the same infection using similar methods and including samples with similar characteristics was markedly low. This review aims to inform healthcare professionals and stakeholders about STI and BV basal risks among lesbian women in different settings and subgroups; therefore, the results were grouped and descriptively presented in categories according to infection and study characteristics. Individual frequencies were described for each study and grouped as minimum and maximum values within each category.

\section{Risk of bias within individual studies}

Assessment of bias was based on the JBI Critical Appraisal Checklist for Studies Reporting Prevalence Data (The Joanna Briggs Institute; http://joannabriggs.org/assets/docs/jbc/operations/criticalAppraisal Forms/JBC_Form_CritAp_Prev.pdf) This risk assessment tool is descriptive and does not provide a score.

\section{Results}

\section{Study selection}

The combined searches yielded 387 potentially relevant studies (Figure 1). After screening, 320 publications were excluded based on title and abstract reading. The main reasons for exclusion in this step were populations not eligible for the purposes of this review (male samples only) or type of publication (case reports, case series, opinion articles). Of the resulting 67 studies, 22 met our inclusion criteria after full-text reading. The main reason for exclusion in this step was the lack of data specifically 


\section{Figure 1}

PRISMA flowchart.

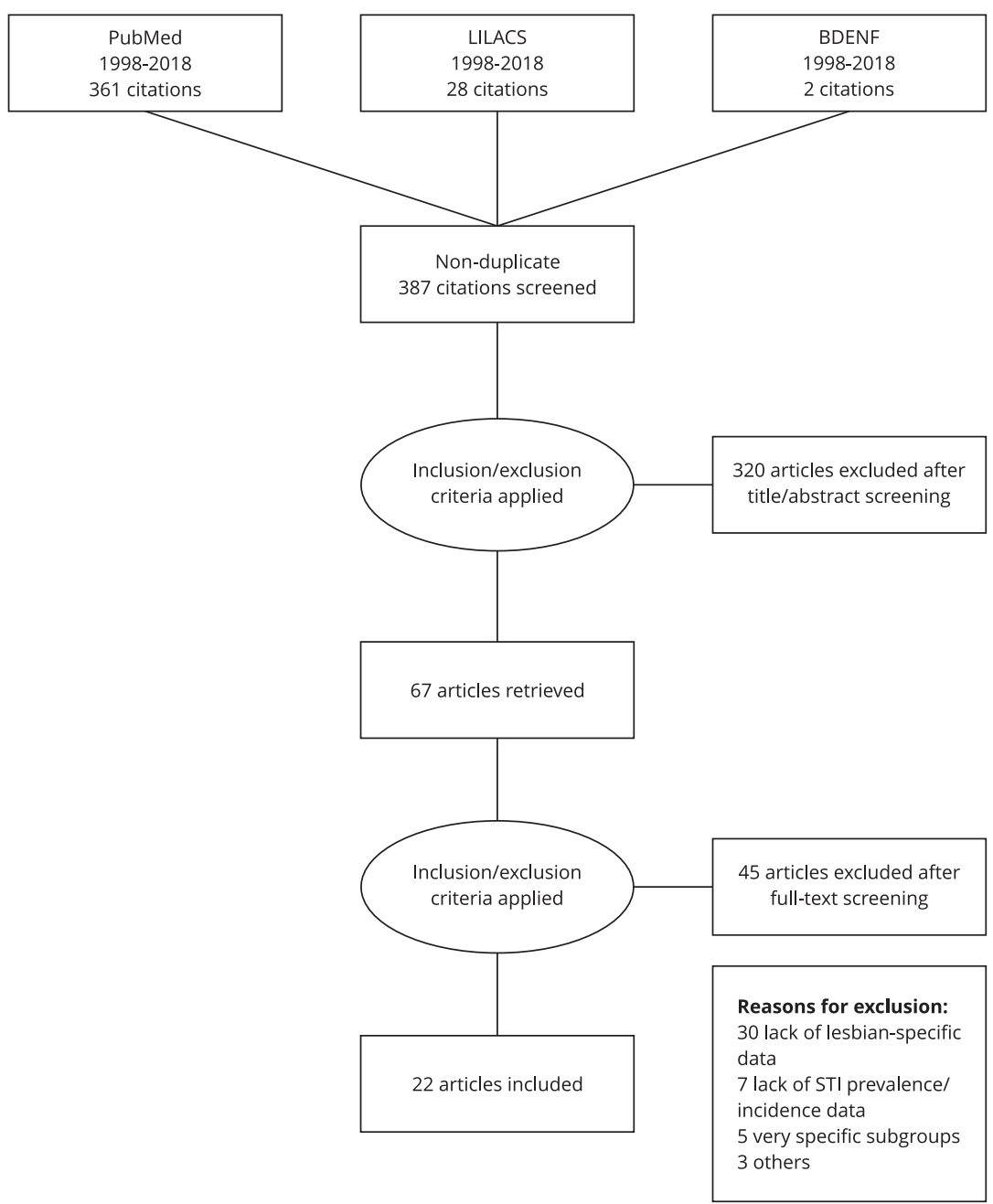

STI: sexually transmitted infections.

for lesbians or WSEW ( $\mathrm{n}=30$ out of 45 exclusions), followed by absence of prevalence/incidence data $(n=7)$, very specific subgroup ( $n=5$; injectable drug users: 3 , drug users: 1 , homeless people: 1$)$, duplicate study $(\mathrm{n}=1)$, narrative literature review $(\mathrm{n}=1)$, and absence of patient-level data $(\mathrm{n}=1)$.

\section{Study characteristics}

Table 1 shows the main characteristics of the studies included. All 22 eligible studies were crosssectional, and two of them a cross-sectional analysis of an ongoing longitudinal study 10,25. The most frequent setting for sample recruitment and selection were STI clinics $(n=6)$, population-based national surveys $(n=5)$, sexual health or genitourinary clinics $(n=4)$, community setting $(n=3)$, LGBT community niches $(n=2)$, internet survey $(n=1)$, and a mixed approach based on community setting and referral from lesbian sexual health clinic $(\mathrm{n}=1)$. When applicable, studies were grouped as population-based national surveys or community setting using the definition described in the publication. 
Table 1

Main characteristics of the studies included in the review.

\begin{tabular}{|c|c|c|c|c|c|}
\hline Study (year) & Country & Setting & Sample characteristics * & STIs investigated & $\begin{array}{l}\text { Method to determine } \\
\text { the diagnosis }\end{array}$ \\
\hline Bailey et al. 26 (2004) & UK & Lesbian sexual health clinic & 708 WSW, 93\% lesbians & BV & $\begin{array}{c}\text { Clinical examination and } \\
\text { laboratory tests }\end{array}$ \\
\hline Bailey et al. 27 (2004) & UK & Lesbian sexual health clinic & 708 WSW, 23\% lesbians & $\begin{array}{c}\text { BV, TV, CT, gonorrhea, } \\
\text { HPV, HSV2 }\end{array}$ & $\begin{array}{c}\text { Clinical examination and } \\
\text { laboratory tests }\end{array}$ \\
\hline $\begin{array}{l}\text { Bauer \& Welles } 58 \\
(2001)\end{array}$ & USA & LGBT community niches & 197 lesbians $(\mathrm{N}=286)$ & Any history of STI & Self-report \\
\hline $\begin{array}{l}\text { Bostwick et al. } 20 \\
\text { (2015) }\end{array}$ & USA & Community setting & 227 lesbians $(\mathrm{N}=366)$ & Any history of STI & Self-report \\
\hline $\begin{array}{l}\text { Branstetter et al. } 21 \\
\text { (2017) }\end{array}$ & USA & Population-based & 96 lesbians $(\mathrm{N}=830)$ & HPV & Laboratory results \\
\hline $\begin{array}{l}\text { Charlton et al. } 10 \\
\text { (2011) }\end{array}$ & USA & Community setting & 59 lesbians $(N=4,224)$ & Any history of STI & Self-report \\
\hline Estrich et al. 22 (2014) & USA & STI clinic & 62 lesbians $(\mathrm{N}=669)$ & $\begin{array}{c}\text { CT/gonorrhea (combined), } \\
\text { any current STI, any } \\
\text { history of STI }\end{array}$ & $\begin{array}{c}\text { Clinical examination and } \\
\text { laboratory tests }\end{array}$ \\
\hline Evans et al. 59 (1998) & UK & Genitourinary clinic & 16 lesbians $(N=948)$ & BV & $\begin{array}{c}\text { Clinical examination and } \\
\text { laboratory tests }\end{array}$ \\
\hline Evans et al. 17 (2007) & UK & LGBT community niches & 171 lesbians $(\mathrm{N}=360)$ & BV & $\begin{array}{c}\text { Clinical examination and } \\
\text { laboratory tests }\end{array}$ \\
\hline Everett 60 (2013) & USA & Population-based & $\begin{array}{c}133 \text { lesbians ( } \mathrm{N}=7,392 \\
\text { adolescents) }\end{array}$ & Any history of STI & Self-report \\
\hline Lindley et al. 23 (2008) & USA & Population-based & $\begin{array}{c}270 \text { lesbians }(\mathrm{N}=29,952 \\
\text { college students) }\end{array}$ & $\begin{array}{c}\text { Any recent STI (past year), } \\
\text { CT, gonorrhea, HPV, HIV, } \\
\text { HSV2 }\end{array}$ & Self-report \\
\hline Logie et al. 53 (2015) & Canada & Internet survey & 121 lesbians $(\mathrm{N}=400)$ & Any history of STI & Self-report \\
\hline $\begin{array}{l}\text { Marrazzo et al. } 29 \\
\text { (1998) }\end{array}$ & USA & $\begin{array}{l}\text { Mix of community setting } \\
\text { and referral from lesbian } \\
\text { sexual health clinic }\end{array}$ & $\begin{array}{l}21 \text { women without MSP } \\
\text { ever }(\mathrm{N}=149)\end{array}$ & HPV & $\begin{array}{c}\text { Clinical examination and } \\
\text { laboratory tests }\end{array}$ \\
\hline Massad et al. 25 (2014) & USA & STI clinic & 73 lesbians $(\mathrm{N}=438)$ & HPV & $\begin{array}{c}\text { Clinical examination and } \\
\text { laboratory tests }\end{array}$ \\
\hline $\begin{array}{l}\text { McCaffrey et al. } 61 \\
\text { (1999) }\end{array}$ & UK & Genitourinary clinic & 15 lesbians ( $N=91)$ & BV & $\begin{array}{c}\text { Clinical examination and } \\
\text { laboratory tests }\end{array}$ \\
\hline Muzny et al. 62 (2011) & USA & STI clinic & $\begin{array}{l}111 \text { women without MSP } \\
\text { in the last year } \star \star ~(N=191 \\
\text { African American women) }\end{array}$ & $\begin{array}{l}\text { Any history of STI, TV, CT, } \\
\text { gonorrhea, syphilis, HIV }\end{array}$ & $\begin{array}{c}\text { Clinical examination and } \\
\text { laboratory tests }\end{array}$ \\
\hline Muzny et al. 34 (2013) & USA & STI clinic & $\begin{array}{c}119 \text { lesbians ( } \mathrm{N}=196 \\
\text { African American women) }\end{array}$ & BV & $\begin{array}{c}\text { Clinical examination and } \\
\text { laboratory tests }\end{array}$ \\
\hline Muzny et al. 31 (2014) & USA & STI clinic & $\begin{array}{l}78 \text { WSW, 92\% lesbians (N } \\
=163 \text { African American } \\
\text { women) }\end{array}$ & $\begin{array}{l}\text { TV, CT, gonorrhea, } \\
\text { syphilis, HIV, HSV2 }\end{array}$ & $\begin{array}{c}\text { Clinical examination and } \\
\text { laboratory tests }\end{array}$ \\
\hline Muzny et al. 45 (2016) & USA & STI clinic & $\begin{array}{c}21 \text { women without MSP } \\
\text { ever ( } \mathrm{N}=63 \text { African } \\
\text { American women) }\end{array}$ & $\mathrm{CT}$ & $\begin{array}{c}\text { Clinical examination and } \\
\text { laboratory tests }\end{array}$ \\
\hline $\begin{array}{l}\text { Sandfort et al. } 30 \\
\text { (2013) }\end{array}$ & $\begin{array}{l}\text { Southern } \\
\text { Africa } * * *\end{array}$ & Community setting & 452 lesbians $(\mathrm{N}=591)$ & HIV & Self-report \\
\hline Tao 32 (2008) & USA & Population-based & 99 lesbians $(\mathrm{N}=7,643)$ & Any history of viral STI & Self-report \\
\hline Xu et al. 63 (2010) & USA & Population-based & 54 lesbians $(N=315)$ & HSV2 & Laboratory results \\
\hline
\end{tabular}

BV: bacterial vaginosis; CT: Chlamydia infection; HIV: human immunodeficiency virus; HPV: human papillomavirus/genital warts; HSV2: genital herpes; LGBT: lesbian, gay, bisexual, and gender nonconforming; MSP: male sexual partner; STI: sexually transmitted infections; TV: Trichomonas infection; WSW: women who have sex with women (without other specification).

* Number in parenthesis indicate the total study sample;

** Very similar to the percentage of self-reported lesbian in the study (111 without MSP in the last year vs. 119 self-identified lesbian);

*** Botswana, Namibia, South Africa and Zimbabwe countries. 
The definition of a lesbian or homosexual woman varied between studies, and self-identification of sexual orientation/sexual identity was the most common one $(\mathrm{n}=8)$, followed by WSW without a MSP in the last five years $(\mathrm{n}=2)$ or who had never had a MSP $(\mathrm{n}=2)$. Two studies did not report separate data for lesbian women but informed a percentage of lesbian women in the sample above $90 \%$ and were thus included 26,27 .

None of the studies included reported incidence data for STIs or BV, and the infections investigated were: BV, genital warts/human papillomavirus (HPV), Trichomonas infection (TV), genital herpes (HSV2), Chlamydia infection (CT), gonorrhea, syphilis, and an HIV positive test. Eight studies reported data about history of any STIs. The most frequent method to determine the presence of STI or BV was clinical examination with laboratory tests $(\mathrm{n}=12)$, followed by self-report $(\mathrm{n}=8)$, and laboratory test only $(\mathrm{n}=2)$.

\section{Assessment of bias}

In terms of sample frame and sampling, most studies used a community setting approach and described how potential participants were recruited (mainly in lesbian festivals, parades, clubs, resource centers, etc.). This method can lead to some selection bias towards lesbian women who actively attend those events and places and may not be representative of a broader population of lesbian women. Also, recruitment in STI clinics potentially increases the prevalence observed, since women may seek for medical care when facing perceived symptoms of an ongoing condition. Thus, population-based surveys are probably less prone to bias in the sampling process. Sample size varied from 15-708 women and all of them relied on convenience sample, without clearly stating a rationale for sample size calculation. Study subjects and settings were appropriately described in all the 22 studies included, and valid methods to determine the presence of the condition were used. Eight studies used self-reported history of STI diagnosis, and recall bias is more likely among them. The statistical analysis plan was deemed appropriate for all the 22 studies, but studies with a smaller sample of lesbian women could be unable to derive robust prevalence estimates or identify relevant risk factors. Overall, risk of bias was assessed as moderate to high.

\section{Results of individual studies}

Table 2 summarizes STI and BV prevalence and risk factors associated with infections reported in the studies included in this review. The most frequent infection reported in the samples was BV, with prevalence ranging from $25.7 \%$ to $42.8 \%$. Most studies reported data on bacterial infections followed by HPV or the presence of genital warts. A wide range of prevalence was observed for most infections. Previous self-reported history of STI ranged from $2.3 \%$ to $56 \%$. The least represented infection was syphilis $(\mathrm{n}=2)$, and no study reported data on hepatitis B (HBV) infection.

Regarding risk factors, the studies included investigated several factors related to sexual behaviors, specific sexual practices, substance abuse, demographic factors, etc. We selected those that could be considered modifiable or directly useful to guide health education strategies targeting lesbian women. Twelve studies did not provide data on risk factors either because of the absence of a multivariate analysis or the fact that the multivariate analysis was performed with an aim that did not allow directly applying the results for lesbian women. Among studies that described useful data, 5 out of 10 studies reported the number of sexual partners (female, male, or total) as a risk factor for a STI diagnosis. A higher number of sexual partners regardless of their sex/gender seems to increase the risk of HPV 21, CT, gonorrhea, HPV, HIV, HSV2 23, and any history of STI 23,28. Conflicting results were found about the association of BV with the number of FSPs. Four studies identified past or current smoking as a risk factor for a STI diagnosis (OR ranging from 1.43 to 3.4) 17,26,27,29. Two studies observed a history of forced sex (by both women or men) increased STI risks (any STI or HIV specifically) 28,30. One study found sexual stigma (both enacted or perceived) increased STI risk 28. 
Table 2

Results of individual studies.

\begin{tabular}{|c|c|c|c|c|c|c|c|c|c|c|}
\hline \multirow[t]{2}{*}{ Study (year) } & \multicolumn{9}{|c|}{ Prevalence (\%) } & \multirow[t]{2}{*}{ Risk factors (OR; $95 \% \mathrm{Cl}$ ) } \\
\hline & BV & TV & CT & Gonorrhea & Syphilis & HSV2 & HPV & HIV & Any STI & \\
\hline $\begin{array}{l}\text { Bailey et al. } 26 \\
\text { (2004) }\end{array}$ & 32.5 & $\mathrm{n} / \mathrm{a}$ & $\mathrm{n} / \mathrm{a}$ & $\mathrm{n} / \mathrm{a}$ & $\mathrm{n} / \mathrm{a}$ & $\mathrm{n} / \mathrm{a}$ & $\mathrm{n} / \mathrm{a}$ & $\mathrm{n} / \mathrm{a}$ & $\mathrm{n} / \mathrm{a}$ & $\begin{array}{c}\text { Lifetime FSPs }(1.60 ; 1.05-2.44) \text {; current } \\
\text { smoking }(1.43 ; 1.01-2.03)\end{array}$ \\
\hline $\begin{array}{l}\text { Bailey et al. } 27 \\
\text { (2004) }\end{array}$ & 31.0 & 1.3 & 0.6 & 0.3 & $\mathrm{n} / \mathrm{a}$ & 1.1 & 1.6 & $\mathrm{n} / \mathrm{a}$ & 4.9 & $\begin{array}{c}\text { Past or current smoking } \\
(2.49 ; 1.18-5.26) \text { * }\end{array}$ \\
\hline $\begin{array}{l}\text { Bauer \& Welles } 58 \\
\text { (2001) }\end{array}$ & $\mathrm{n} / \mathrm{a}$ & $\mathrm{n} / \mathrm{a}$ & $\mathrm{n} / \mathrm{a}$ & $\mathrm{n} / \mathrm{a}$ & $\mathrm{n} / \mathrm{a}$ & $\mathrm{n} / \mathrm{a}$ & $\mathrm{n} / \mathrm{a}$ & $\mathrm{n} / \mathrm{a}$ & 15.0 & Lifetime MSPs $(1.07 ; 1.03-1.12)$ * \\
\hline $\begin{array}{l}\text { Bostwick et al. } 20 \\
\text { (2015) }\end{array}$ & $\mathrm{n} / \mathrm{a}$ & $\mathrm{n} / \mathrm{a}$ & $\mathrm{n} / \mathrm{a}$ & $\mathrm{n} / \mathrm{a}$ & $\mathrm{n} / \mathrm{a}$ & $\mathrm{n} / \mathrm{a}$ & $\mathrm{n} / \mathrm{a}$ & $\mathrm{n} / \mathrm{a}$ & 20.3 & Not assessed \\
\hline $\begin{array}{l}\text { Branstetter et } \\
\text { al. } 21 \text { (2017) }\end{array}$ & $\mathrm{n} / \mathrm{a}$ & $\mathrm{n} / \mathrm{a}$ & $\mathrm{n} / \mathrm{a}$ & $\mathrm{n} / \mathrm{a}$ & $\mathrm{n} / \mathrm{a}$ & $\mathrm{n} / \mathrm{a}$ & $35.5 / 26.7 * *$ & $\mathrm{n} / \mathrm{a}$ & $\mathrm{n} / \mathrm{a}$ & $\begin{array}{c}\text { Black women }(1.59 ; 1.01-2.48) ; \geq 5 \\
\quad \text { lifetime SPs }(4.59 ; 2.14-9.86)\end{array}$ \\
\hline $\begin{array}{l}\text { Charlton et al. } 10 \\
\text { (2011) }\end{array}$ & $\mathrm{n} / \mathrm{a}$ & $\mathrm{n} / \mathrm{a}$ & $\mathrm{n} / \mathrm{a}$ & $\mathrm{n} / \mathrm{a}$ & $\mathrm{n} / \mathrm{a}$ & $\mathrm{n} / \mathrm{a}$ & 8.0 & $\mathrm{n} / \mathrm{a}$ & 8.0 & Not assessed \\
\hline $\begin{array}{l}\text { Estrich et al. } 22 \\
\text { (2014) }\end{array}$ & $\mathrm{n} / \mathrm{a}$ & $\mathrm{n} / \mathrm{a}$ & $\begin{array}{r}5.0( \\
g\end{array}$ & $\begin{array}{l}\text { chlamydia + } \\
\text { onorrhea) }\end{array}$ & $\mathrm{n} / \mathrm{a}$ & $\mathrm{n} / \mathrm{a}$ & $\mathrm{n} / \mathrm{a}$ & $\mathrm{n} / \mathrm{a}$ & $\begin{array}{c}6.7 * * \star \\
18.3 \#\end{array}$ & Not assessed \\
\hline $\begin{array}{l}\text { Evans et al. } 59 \\
\text { (1998) }\end{array}$ & 37.5 & $\mathrm{n} / \mathrm{a}$ & $\mathrm{n} / \mathrm{a}$ & $\mathrm{n} / \mathrm{a}$ & $\mathrm{n} / \mathrm{a}$ & $\mathrm{n} / \mathrm{a}$ & $\mathrm{n} / \mathrm{a}$ & $\mathrm{n} / \mathrm{a}$ & $\mathrm{n} / \mathrm{a}$ & Not assessed \\
\hline $\begin{array}{l}\text { Evans et al. } 17 \\
\text { (2007) }\end{array}$ & 25.7 & $\mathrm{n} / \mathrm{a}$ & $\mathrm{n} / \mathrm{a}$ & $\mathrm{n} / \mathrm{a}$ & $\mathrm{n} / \mathrm{a}$ & $\mathrm{n} / \mathrm{a}$ & $\mathrm{n} / \mathrm{a}$ & $\mathrm{n} / \mathrm{a}$ & $\mathrm{n} / \mathrm{a}$ & Current smoking $(2.65 ; 1.49-4.72)$ \\
\hline $\begin{array}{l}\text { Everett et al. } 60 \\
(2013)\end{array}$ & $\mathrm{n} / \mathrm{a}$ & $\mathrm{n} / \mathrm{a}$ & $\mathrm{n} / \mathrm{a}$ & $\mathrm{n} / \mathrm{a}$ & $\mathrm{n} / \mathrm{a}$ & $\mathrm{n} / \mathrm{a}$ & $\mathrm{n} / \mathrm{a}$ & $\mathrm{n} / \mathrm{a}$ & 32.0 & Not assessed \\
\hline $\begin{array}{l}\text { Lindley et al. } 23 \\
\text { (2008) }\end{array}$ & $\mathrm{n} / \mathrm{a}$ & $\mathrm{n} / \mathrm{a}$ & 0.4 & 0.0 & $\mathrm{n} / \mathrm{a}$ & 1.5 & 1.1 & 0.0 & 2.3 & $\begin{array}{c}\text { Binge drinking }(1.27 ; 1.04-1.56) ; \\
\geq 2 \text { sexual partner in } 1 \text { year } \\
(1.99 ; 1.62-2.43) \text {; gynecologic exam in } \\
1 \text { year }(4.00 ; 2.64-6.06) ; \text { HIV test ever } \\
(2.14 ; 1.75-2.62) \text { * }\end{array}$ \\
\hline $\begin{array}{l}\text { Logie et al. } 53 \\
(2015)\end{array}$ & $\mathrm{n} / \mathrm{a}$ & $\mathrm{n} / \mathrm{a}$ & $\mathrm{n} / \mathrm{a}$ & $\mathrm{n} / \mathrm{a}$ & $\mathrm{n} / \mathrm{a}$ & $\mathrm{n} / \mathrm{a}$ & $\mathrm{n} / \mathrm{a}$ & $\mathrm{n} / \mathrm{a}$ & 10.0 & $\begin{array}{c}\text { MSP in } 3 \text { months }(3.52 ; 2.06-6.02) ; \\
\text { Lifetime sexual partners }(1.03 ; 1.01- \\
\text { 1.04); previous forced sex }(2.38 ; \\
\text { 1.44-3.93); STI test ever }(3.89 ; 1.49- \\
\text { 10.14); Pap in } 2 \text { years }(2.38 ; 1.24-4.56) ; \\
\text { enacted (6.50; } 1.10-38.31) ; \text { perceived } \\
\text { sexual stigma ( } 2.09 ; 1.08-4.03) \text { * }\end{array}$ \\
\hline $\begin{array}{l}\text { Marrazzo et al. } 29 \\
\text { (1998) }\end{array}$ & $\mathrm{n} / \mathrm{a}$ & $\mathrm{n} / \mathrm{a}$ & $\mathrm{n} / \mathrm{a}$ & $\mathrm{n} / \mathrm{a}$ & $\mathrm{n} / \mathrm{a}$ & $\mathrm{n} / \mathrm{a}$ & 19.0 & $\mathrm{n} / \mathrm{a}$ & $\mathrm{n} / \mathrm{a}$ & Current smoking $(3.4 ; 1.2-9.6)$ \\
\hline $\begin{array}{l}\text { Massad et al. } 25 \\
\text { (2014) }\end{array}$ & $\mathrm{n} / \mathrm{a}$ & $\mathrm{n} / \mathrm{a}$ & $\mathrm{n} / \mathrm{a}$ & $\mathrm{n} / \mathrm{a}$ & $\mathrm{n} / \mathrm{a}$ & $\mathrm{n} / \mathrm{a}$ & $27.3 / 4.6 * *$ & $\mathrm{n} / \mathrm{a}$ & $\mathrm{n} / \mathrm{a}$ & Not assessed \\
\hline $\begin{array}{l}\text { McCaffrey et } \\
\text { al. } 61 \text { (1999) }\end{array}$ & 40.0 & $\mathrm{n} / \mathrm{a}$ & $\mathrm{n} / \mathrm{a}$ & $\mathrm{n} / \mathrm{a}$ & $\mathrm{n} / \mathrm{a}$ & $\mathrm{n} / \mathrm{a}$ & $\mathrm{n} / \mathrm{a}$ & $\mathrm{n} / \mathrm{a}$ & $\mathrm{n} / \mathrm{a}$ & Not assessed \\
\hline $\begin{array}{l}\text { Muzny et al. } 62 \\
\text { (2011) }\end{array}$ & $\mathrm{n} / \mathrm{a}$ & 15.3 & 13.5 & 2.7 & 3.6 & $\mathrm{n} / \mathrm{a}$ & $\mathrm{n} / \mathrm{a}$ & 1.8 & $37.8 * * *$ & Not assessed \\
\hline $\begin{array}{l}\text { Muzny et al. } 34 \\
\text { (2013) }\end{array}$ & 42.8 & $\mathrm{n} / \mathrm{a}$ & $\mathrm{n} / \mathrm{a}$ & $\mathrm{n} / \mathrm{a}$ & $\mathrm{n} / \mathrm{a}$ & $\mathrm{n} / \mathrm{a}$ & $\mathrm{n} / \mathrm{a}$ & $\mathrm{n} / \mathrm{a}$ & $\mathrm{n} / \mathrm{a}$ & Lifetime FSPs $(0.08 ; 0.01-0.74)$ \\
\hline $\begin{array}{l}\text { Muzny et al. } 31 \\
\text { (2014) }\end{array}$ & 33.0 & 17.0 & 3.0 & $\mathrm{n} / \mathrm{a}$ & 1.0 & 26.0 & $\mathrm{n} / \mathrm{a}$ & 1.0 & $\begin{array}{l}23.0 \text { (curable) } * * \star \\
56.0(\text { all) } * \star *\end{array}$ & Not assessed \\
\hline $\begin{array}{l}\text { Muzny et al. } 45 \\
\text { (2016) }\end{array}$ & $\mathrm{n} / \mathrm{a}$ & $\mathrm{n} / \mathrm{a}$ & $\begin{array}{c}33.3 \\
\# \#\end{array}$ & $\mathrm{n} / \mathrm{a}$ & $\mathrm{n} / \mathrm{a}$ & $\mathrm{n} / \mathrm{a}$ & $\mathrm{n} / \mathrm{a}$ & $\mathrm{n} / \mathrm{a}$ & $\mathrm{n} / \mathrm{a}$ & Not assessed \\
\hline
\end{tabular}

(continues) 
Table 2 (continued)

\begin{tabular}{|c|c|c|c|c|c|c|c|c|c|c|}
\hline \multirow[t]{2}{*}{ Study (year) } & \multicolumn{9}{|c|}{ Prevalence (\%) } & \multirow[t]{2}{*}{ Risk factors (OR; 95\%CI) } \\
\hline & BV & TV & CT & Gonorrhea & Syphilis & HSV2 & HPV & HIV & Any STI & \\
\hline $\begin{array}{l}\text { Sandfort et al. } 30 \\
\text { (2013) }\end{array}$ & $\mathrm{n} / \mathrm{a}$ & $\mathrm{n} / \mathrm{a}$ & $\mathrm{n} / \mathrm{a}$ & $\mathrm{n} / \mathrm{a}$ & $\mathrm{n} / \mathrm{a}$ & $\mathrm{n} / \mathrm{a}$ & $\mathrm{n} / \mathrm{a}$ & 10.9 & $\mathrm{n} / \mathrm{a}$ & $\begin{array}{l}\text { Previous forced sex: men only (3.33; } \\
\text { 1.28-8.70); women only (4.19; 1.21- } \\
\text { 14.47); both men and women (5.48; } \\
1.70-17.63)\end{array}$ \\
\hline Tao 32 (2008) & $\mathrm{n} / \mathrm{a}$ & $\mathrm{n} / \mathrm{a}$ & $\mathrm{n} / \mathrm{a}$ & $\mathrm{n} / \mathrm{a}$ & $\mathrm{n} / \mathrm{a}$ & $\mathrm{n} / \mathrm{a}$ & $\mathrm{n} / \mathrm{a}$ & $\mathrm{n} / \mathrm{a}$ & 2.3 (viral) & Not assessed \\
\hline Xu et al. 63 (2010) & $\mathrm{n} / \mathrm{a}$ & $\mathrm{n} / \mathrm{a}$ & $\mathrm{n} / \mathrm{a}$ & $\mathrm{n} / \mathrm{a}$ & $\mathrm{n} / \mathrm{a}$ & 8.2 & $\mathrm{n} / \mathrm{a}$ & $\mathrm{n} / \mathrm{a}$ & $\mathrm{n} / \mathrm{a}$ & Not assessed \\
\hline
\end{tabular}

95\%Cl: 95\% confidence interval; BV: bacterial vaginosis; CT: Chlamydia infection; FSP: female sexual partner; HIV: human immunodeficiency virus; HPV: human papillomavirus/genital warts; HSV2: genital herpes; MSP: male sexual partner; n/a: not applicable; OR: odds ratio; STI: sexually transmitted infection.

* Indicates an OR applicable to any STI;

** Total HPV/high-risk HPV;

*** Current;

\# Previous history;

\#\# Serology results (indicating previous contact), 0\% current diagnosis.

\section{Synthesis of results}

Considering the wide variation in methodological approaches present in the studies, we grouped results by characteristics that could potentially lead to bias: the setting of recruitment (health clinics vs. other settings) and the diagnostic method (self-reported vs. laboratory \pm clinical examination). For this analysis, prevalence data on specific infections reported with a different approach than most studies were excluded for the following reasons: any history of STI excluding BV reported by Bailey et al. 27; CT and gonorrhea presented as a composite endpoint by Estrich et al. 22; current diagnosis of any STI or grouped STIs reported by Estrich et al. 22 and Muzny et al. 31; history of any viral STI reported by Tao 32. The minimum and maximum values for each STI are shown in Table 3.

The synthesis proposed showed that BV and syphilis results showed low variation in the prevalence reported, but BV analysis comprised more studies (7 vs. 2 for syphilis). For gonorrhea, the range was small but it is worth mentioning that the only study that differed in methodological terms (a population-based study relying on self-report) described a prevalence of $0 \% 23$. HSV2 prevalence ranged from $1.1 \%$ to $26 \%$ for all studies, but the analysis according to the setting for recruitment showed the range was smaller for studies conducted in settings other than clinics. The diagnostic method significantly affected HPV prevalence, with self-report and laboratory test ranges of $1 \%-8 \%$ and $1 \%-40 \%$, respectively.

\section{Discussion}

To our knowledge, this is the first systematic review addressing simultaneously different STI and BV risks specifically among lesbian cisgender women. Most studies examining this topic enrolled WSW regardless of their sexual orientation, which is reasonable since the STI transmission chain is usually related to sexual practices/behaviors and not to sexual orientation. However, we aimed to discuss this topic beyond biological aspects of transmission, considering sexual orientation as relevant to comprehensively understand risks and to plan tailored interventions.

We have found the most frequently investigated and the most prevalent condition among lesbian women is BV. BV is not usually considered a STI, and most guidelines state there is no need to treat the partner. However, the referred partner is usually male, and sperm contact is often mentioned as a risk factor for imbalance in the vaginal microbiota, predisposing to BV (what is not usually applicable to lesbian women) 33. The findings by Evans et al. 17 may contribute to a better understanding of BV as a potential STI between MSP, supporting observations from previous studies 18,19 . The authors found 


\section{Table 3}

Synthesis of results: minimum and maximum values for each sexually transmitted infection and bacterial vaginosis prevalence (\%).

\begin{tabular}{|c|c|c|c|c|c|c|}
\hline & \multirow{2}{*}{\multicolumn{2}{|c|}{$\begin{array}{l}\text { Genitourinary, sexual health or STI } \\
\text { clinics } \\
\text { Laboratory results } \pm \text { clinical } \\
\text { examination }\end{array}$}} & \multicolumn{4}{|c|}{ Other settings * } \\
\hline & & & \multicolumn{2}{|c|}{ Self-reported diagnosis } & \multicolumn{2}{|c|}{$\begin{array}{c}\text { Laboratory results } \pm \text { clinical } \\
\text { examination }\end{array}$} \\
\hline & Minimum & Maximum & Minimum & Maximum & Minimum & Maximum \\
\hline BV & 31.0 & 42.8 & $* *$ & ** & 25.7 & $\star \star \star *$ \\
\hline TV & 1.3 & 17.0 & ** & ** & ** & $\star *$ \\
\hline Ст & 0.6 & 13.5 & 0.4 & & $* *$ & $* *$ \\
\hline Gonorrhea & 0.6 & 2.7 & $\star \star$ & $\star \star$ & ** & $\star *$ \\
\hline Syphilis & 1.0 & 3.6 & $\star *$ & ** & ** & $\star *$ \\
\hline HSV2 & 1.1 & 26.0 & 1.5 & $* \star *$ & 8.2 & $* \star *$ \\
\hline HPV & 1.0 & 40.0 & 1.1 & 8.0 & 19.0 & 35.5 \\
\hline HIV & 1.0 & 1.8 & ** & ** & ** & ** \\
\hline Any STI history & 4.9 & 37.8 & 2.3 & 32.0 & ** & ** \\
\hline
\end{tabular}

BV: bacterial vaginosis; CT: Chlamydia infection; HIV: human immunodeficiency virus; HPV: human papillomavirus/genital warts; HSV2: genital herpes; STI: sexually transmitted infections; TV: Trichomonas infection.

* Population-based surveys, community setting, LGBT community niches and internet survey;

** None study contributed to the category;

*** Only one study contributed to the category.

lesbian women had a significantly higher prevalence of BV compared with heterosexual women $(\mathrm{OR}=2.05 ; 95 \% \mathrm{CI}: 1.16-3.64 ; \mathrm{p}=0.011)$ and assessed the concordance of vaginal flora among 33 lesbian partners enrolled in the study, observing concordant microbiota in $87 \%$ of couples (when both partners had BV or both had no BV). The authors hypothesized that concordance of vaginal flora may support a potential sexual transmission but can also reflect common risk factors shared by the couple. Considering the results of other studies included, an increased number of FSP (but not MSP) seems a consistent risk factor for BV 17,26,27,34, which can also be similarly interpreted. In any case, the high prevalence of BV observed in the studies and the lack of specific orientations for lesbian women in official guidelines impose additional risks for this population, since $\mathrm{BV}$ is considered a risk factor for the acquisition of STIs, including HIV 33.

The prevalence data we observed need to be interpreted considering data from other populations. Newman et al. 35 described global estimates of chlamydia, gonorrhea, trichomoniasis and syphilis prevalence in 2012, based on systematic review and World Health Organization (WHO) estimates. For women in lower-middle income countries, the estimated prevalence of these infections was $2.4 \%$, $0.6 \%, 3.5 \%$ and $0.5 \%$, respectively, excluding women seeking care for STI, symptomatic or attending gynecology or sexual health clinics 35 . For HPV infection, estimates from systematic reviews indicate a prevalence ranging from 11\%-15.6\% 36,37,38. Regarding BV, Brazilian estimates from healthy women regardless of sexual orientation ranges from $20 \%-30.1 \%$, lower than the described for lesbian women in the studies included 39,40. Differences in methods and sample characteristics impair the comparability of these data, but identifying that the prevalence among lesbian women is not deniable is possible and some of our findings fall within the ranges observed for other female populations.

The STIs examined in most studies are considered curable or treatable. However, incurable infections with long-term adverse impacts upon women's health and quality of life were poorly investigated. Studies assessing HIV risk were scarce, and no study about HBV was found. Actually, lesbian sex or female-to-female sexual contact is considered a less risky practice for HIV, being recognized as a less effective route of transmission compared with sex involving men. Despite this relative low risk, sexual acts between women are not HIV risk free. In March 2014, the U.S. Centers for Disease Control and Prevention released a report about a case of likely female-to-female sexual transmission 
of HIV, in which epidemiological and phylogenetic analysis supported the hypothesis that a seronegative woman acquired an identical variety of HIV carried by her female seropositive partner in a monogamous relationship without other risk factors. The report also mentioned other previous similar documented case in Africa ${ }^{41}$. In both cases, the female partners were known to have HIV, and epidemiological investigation concluded that sharing insertive sex toys occasionally causing trauma enough to draw blood could be the transmission source. The report from Africa informed that the seropositive partner was bisexual and used barrier protection only with MSP, as instructed by her physician, highlighting the inability of care providers to recognize the potential risk of HIV transmission between women and showing not providing tailored information might lead to dramatic consequences 42. Despite the apparent lack of data on HBV transmission, believing that its transmission is more likely to occur than that of HIV is reasonable, once HBV shows higher infectivity and remains viable for a longer period of time outside the human body 33 .

Most of the studies included somehow assessed risk factors for STIs or BV, but only 10 out of 22 reported them in a manner we could draw conclusions for lesbian women. Four publications identified that past or current smoking is a risk factor for BV (two studies), HPV/genital warts, and other STIs. However, smoking and its association mechanism with STIs is still unclear. One hypothesis is that tobacco exposure seems to increase nicotine levels in cervical/vaginal fluids and alter the vaginal microbiota 43,44 , perhaps predisposing to STIs. The number of sexual partners (recent or lifetime) was investigated in six studies, and different associations were found for FSPs or MSPs. It seems that a larger number of lifetime FSPs increases BV risk, while the recent or lifetime MSP number is associated with a history of any STI. Two studies observed that increased access to healthcare services (gynecological consultations, STI tests, pap smears) is associated with a higher risk of STI 23,28. Still, such data need to be interpreted with caution, since they probably reflect higher diagnosis rates among women with better access, as well as underdiagnosis among those facing difficulties in seeking or accessing health services (financial barriers, lack of trust in the health system or disbelief in its effectiveness, fear of discrimination, expectation of rejection, past negative experiences, etc.).

Two sets of risk factors for STI need special consideration: a history of forced sex (with men, women, or both) and sexual stigma (enacted or perceived). Logie et al. 28 specifically investigated the impact of sexual stigma on STI risk among WSW in Canada. Sexual stigma is defined by the authors as the social process that undervalues, disempowers and creates barriers to access opportunities for sexual minority people, also limiting access to adequate healthcare and HIV/STI prevention, treatment, and care. In their analysis, enacted sexual stigma (having experienced actual acts of violence and discrimination) increased the odds of STI by 6.5 times, while perceived sexual stigma (being aware of negative social attitudes towards sexual orientation) increased this odd by 2.09 times. In terms of sexual violence, Logie et al. 28 found a history of forced sex in $41.7 \%$ of their sample, Sandford et al. 30 observed this proportion as being $31.1 \%$ of Southern African WSW (14.9\% by men only, $6.6 \%$ by women only, and $9.6 \%$ by both women and men), while 5 out of 21 African American exclusive WSW enrolled in the study of Muzny et al. 45 had a lifetime history of sexual assault. In Sandford et al. 30, age and having experienced forced sex were the only factors independently associated with a HIV positive serostatus among several variables examined, such as injectable drug use, number of female and male partners, and transactional sex. Logie et al. 28 observed a history of forced sex increased STI risk by 2.38 times (adjusted $\mathrm{OR}=2.38$; 95\%CI: 1.44-3.93; $\mathrm{p}$-value $=0.003$ ), also after controlling for numerous factors. These issues are important and their interactions need to be addressed by healthcare providers, since there is a well-recognized higher risk of sexual violence (even "corrective rape" events) among lesbian and bisexual women. Additionally, prejudice and stigma within the healthcare system may impair their will to seek for immediate health care. Including sexual stigma and sexual violence information in culturally competent personal history questions for lesbian women attending health services would be also recommended. Moreover, providers should improve the communication with victims of sexual violence, avoiding assumptions of heterosexuality, thus allowing them to feel comfortable to express their sexual orientation or sexual behaviors if this information can help plan and provide a better care.

Prejudice, stigma, and lack of knowledge by healthcare providers, as well as fear, distrust, and a perception of the individuals' lack of risk are usually referred as root causes of health outcomes disparities among the LGBT community 2,3,4,5. Barriers usually start with lack of sexual orientation 
disclosure, followed by inability of health professionals to create a nonjudgmental and open environment to help communication. A systematic review of 31 studies involving 2,442 sexual minority participants identified barriers to sexual orientation disclosure 46. Most of them were considered modifiable and potential targets of comprehensive interventions, such as eliminating heteronormative language, creating explicit opportunities during conversation, ensuring confidentiality, removing religious icons, avoiding poor response to disclosure, among others.

One highlights that health education towards a better sexual health demands sharing high-quality information about STI risks and risk reduction strategies. International guidelines about sexual health that explicitly address lesbian sex usually focus STI prevention on the use of safer sex practices 16,47,48, describing these practices as being: using barrier protections (gloves during digital-genital sex, condoms on insertive sex toys, latex or plastic barriers for oral sex), avoiding sex toy sharing, cleaning sex toys before sharing, and avoiding contact with menstrual blood or genital lesions. None of them gives clear information on how barriers should be used, which may reveal an assumption that lesbian women or their care providers have already this information. In fact, studies assessing barrier protection use among lesbian women indicate infrequent, inadequate, or absent use. An Australian survey with 543 lesbians or WSW observed that, among those who had had oral sex with a woman in the previous six months, only $9.7 \%$ had used a dental dam (a sheet of latex rubber used as a barrier between the mouth and vulva or anus) and $2.1 \%$ had used one "often" 49 . In Brazil, Pinto et al. 13 also observed an infrequent use of safe sex practices in a sample with a relative high prevalence of STIs; and other studies also observed that in other contexts 50,51. Interventional studies also observed even within the context of trials with tailored educational and behavioral interventions to improve safer sex practices among lesbian women, the use of barriers is either inconsistent or ineffective 52,53 . Therefore, assuming that knowledge about safer sex practices is widespread or common sense is not possible, probably even less likely among care providers. Thus, straightforward information is needed in guidelines, official documents, initial and continuing professional education, educational aids, etc.

To improve the skills of care providers to approach these questions in a sensitive and respectful way, an essential strategy would be ensuring that healthcare professionals' education include contents about lesbian women health needs. However, these contents in health science school curricula are either scarce or nonexistent. Investigations in the USA, Canada, and South Africa medical schools showed even those students who reported being comfortable about caring for LGBT persons feel unprepared to deal with their specific health issues 54,55. Solotke et al. 56 discussed strategies for incorporating and teaching sexual and gender minority health curricular content in undergraduate education and highlighted that the existence of logistical and structural barriers and difficulties in identifying effective pedagogical methods for teaching sexual and gender minority topics. Based on their real-life experience, the authors provide 12 tips to help educators incorporate sexual and gender minority content in curricula, such as creating a common language around sexual orientation and gender identity; distributing sexual and gender minority health content throughout the curriculum; exploring the complexities of questioning, exploring, and forming a sexual and gender minority identity and their relevance to health; and presenting sexual and gender minority population-specific health content. These proposals clarify that approaching LGBT health topics is not an exclusive task of specific disciplines within the curricula (e.g., gynecology in the context of lesbian women) and that students need longitudinal opportunities to develop skills to improve care for the LGBT community 56 .

After critically reviewing the studies included and the literature pertinent to the major topic of STI prevention among lesbian women and barriers to implement adequate care, we still need an effort to understand lesbian women particularities to propose recommendations that meet their needs. The overall quality of the studies reviewed was generally low or very low with significant uncertainty around the prevalence estimates and the risk factors reported. In the local setting, the Brazilian Clinical Protocol and Therapeutic Guidelines for the Comprehensive Care of People with Sexually Transmitted Diseases 33 does not have specific section or recommendations on how to prevent, screen, or treat STIs in lesbian women, and most information could be considered heteronormative or directed to men who have sex with men only. International guidelines propose specific recommendations, but the focus on barrier protection needs more real-life information and perhaps has to be revisited, since the effectiveness of educational strategies to raise awareness of their use seems to be poor. 
Having this in mind, we propose some general interventions that may improve the preventive care for lesbian women:

- Improving the communication skills of healthcare providers to facilitate sexual orientation disclosure and frank conversations about sexual behaviors and practices, which also involves attention to the setting and location of the consultations and eliminating heteronormative language and questions that can configure microaggressions;

- Giving relevant meaningful orientation about barrier protections applicable for lesbian women, which requires real-world information about the available barriers, where they can be obtained, how to handle them, and where and when they should be used to reduce the exposure to body fluids. Considering the obstacles lesbian women anticipate and actually face while using them in the conversation can be achieved by asking lesbian womenthem in a nonjudgmental environment. Also, one needs to consider that some sexual practices do not have an adequate barrier available to use, which is the case of genital rubbing;

- Giving relevant meaningful information about how to increase the safety of sex toy use in lesbian sex, such as avoiding sharing insertive sex toys, changing condoms, or cleaning the sex toys before sharing. Particular attention should be given to reinforcing of the need of barriers (condom, gloves) for practices that may cause traumas;

- Informing lesbian women that the recommendation is to avoid contact with menstrual blood and visible genital lesions, but highlighting that, even without exposure to blood or visible lesions, the transmission of STIs is possible by contact with cervical/vaginal fluids and physiological lubrication; - Giving information on smoking cessation programs and strategies, since smoking seems to be a consistent risk factor for STIs among lesbian women. Explaining the rationale behind this hypothesis, informing that even passive smoking may alter the microbiota, predisposing to infections 37. Asking whether the partner (or partners) also smokes and including the person in the intervention, if applicable;

- Informing about HBV vaccination if not yet immune, since the vaccine is currently available within the Brazilian National Immunization Program for people of all ages regardless of any risk status. Also, offering vaccine for the partner or partners, if applicable. Despite the lack of information about HBV prevalence among lesbian women, female-to-female transmission is likely to occur, and adequate vaccination may be more effective than barrier protection, considering typical use difficulties;

- Teaching women about signs and symptoms of STIs and BV and when they need to seek health services for tests and treatment, also informing about the primarily asymptomatic infections. Following national recommendations to offer STI screening (HIV, syphilis, HBV, gonorrhea, and chlamydia) for all women attending a health service because of abnormal vaginal discharge, regardless of the final diagnosis. Not considering lesbian women as at less risk of STIs and giving special attention to BV because of its prevalence and high rates of persistence 52,57. Offering treatment and additional STI screening for the partner or partners, if applicable, even if the final diagnosis is of BV only;

- Building consistent strategies to transform health services into welcoming and inviting environments for lesbian women (and other sexual minorities) to improve their access and their experiences within the healthcare system. This can be achieved by explicit and visible educational materials and campaigns, inclusive language in signs and forms, but mainly by meaningful education and training of healthcare providers at all levels of care.

Our review has shown that studies about STI risk among lesbian women are scarce and that some of them had a very small sample size of lesbian women and adopted different methodological approaches, diagnostic criteria, and sample composition. Thus, we could not pool data or identify a clear prevalence pattern for all the infections investigated. Furthermore, we relied on the definition of the studies for lesbian cisgender women, and not all of them clearly stated the approach used (whether it was self-reporting or which classification options were available to women in the questionnaires/ interviews, for example). Other limitations of our review include the limited number of databases searched and restrictions of publication language. Despite these limitations, we consider that our findings may help healthcare providers and policy decision-makers to better understand the current knowledge about STI and BV risks in this population, and we also highlight gaps in the literature that may prioritize further research efforts about the topic - ideally through population-based studies relying on laboratory test diagnosis, collecting data on risk factors. 


\section{Conclusion}

Affirming that little is known about the extent of STI and BV transmission in female-to-female sexual activities or about the risk factors for STIs and BV among lesbian cisgender women is reasonable. Safe sexual practices, despite being widely advocated by those who discuss lesbian sexual health, are inconsistently used, with scarce or absent information about their effective ideal use in guidelines and protocols in Brazil or worldwide. Healthcare providers should be trained to identify and handle the vulnerabilities affecting these women, including learning how to avoid prejudice and discrimination during interview and physical examination. We consider that the available knowledge indicates some paths to be followed by care providers to improve their actions towards a better sexual health for lesbian women. However, further studies are needed to comprehensively describe STI risks and safe sex practices among lesbian women (preferably population-based studies relying on laboratory test diagnosis), and bisexual and transgender people, so that health interventions may be better designed to address the LGBT community. Furthermore, public policies must be developed and implemented to ensure that the particularities of this community are addressed in health programs, as well as in health professionals' initial and permanent education.

\section{Contributors}

M. L. S. Takemoto, M. O. Menezes and R. Knobel participated in the design and conduct of the review, data interpretation and analysis, drafting of the manuscript versions, critical review of the content and approval of the final version. C. B. A. Polido and D. S. Santos participated in the data interpretation and analysis, drafting of the manuscript versions, critical review of the content and approval of the final version. V. M. Leonello, C. G. Magalhães and J. F. Cirelli participated in the drafting of the manuscript versions, critical review of the content and approval of the final version.

\section{Additional informations}

ORCID: Maira Libertad Soligo Takemoto (00000002-7016-2879); Mariane de Oliveira Menezes (0000-0002-8525-0521); Carla Betina Andreucci Polido (0000-0002-5590-108X); Débora de Souza Santos (0000-0001-9060-3929); Valeria Marli Leonello (0000-0003-0557-484X); Claudia Garcia Magalhães (0000-0001-7033-1807); Jessica Fernandes Cirelli (0000-0001-9066-8538); Roxana Knobel (0000-0001-9180-4685).

\section{References}

1. Barbosa RM, Facchini R. Acesso a cuidados relativos à saúde sexual entre mulheres que fazem sexo com mulheres em São Paulo, Brasil. Cad Saúde Pública 2009; 25 Suppl 2:S291-300.

2. Valadão RC, Gomes R. A homossexualidade feminina no campo da saúde: da invisibilidade à violência. Physis (Rio J.) 2011; 21:1451-67.

3. Lim FA, Brown DV, Justin Kim SM. Addressing health care disparities in the lesbian, gay, bisexual, and transgender population: a review of best practices. Am J Nurs 2014; 114:24-34.

4. Fredriksen-Goldsen KI, Simoni JM, Kim H-J, Lehavot K, Walters KL, Yang J, et al. The health equity promotion model: reconceptualization of lesbian, gay, bisexual, and transgender (LGBT) health disparities. Am J Orthopsychiatry 2014; 84:653-63.

5. Cahill S, Makadon H. Sexual orientation and gender identity data collection in clinical settings and in electronic health records: a key to ending LGBT health disparities. LGBT Health 2014; 1:34-41.

6. Ministério da Saúde. Política nacional de saúde integral de lésbicas, gays, bissexuais, travestis e transsexuais. Brasília: Ministério da Saúde; 2012.

7. Conselho Nacional de Saúde. Relatório final da 13a Conferência Nacional de Saúde. Brasília: Conselho Nacional de Saúde; 2008.

8. Almeida G. Argumentos em torno da possibilidade de infecção por DST e aids entre mulheres que se autodefinem como lésbicas. Physis (Rio J.) 2009; 19:301-31.

9. Reiter PL, McRee A-L. Cervical cancer screening (Pap testing) behaviours and acceptability of human papillomavirus self-testing among lesbian and bisexual women aged 21-26 years in the USA. J Fam Plan Reprod Health Care 2015; 41:259-64. 
10. Charlton BM, Corliss HL, Missmer SA, Frazier AL, Rosario M, Kahn JA, et al. Reproductive health screening disparities and sexual orientation in a cohort study of U.S. adolescent and young adult females. J Adolesc Health 2011; 49:505-10.

11. Mello L, Perilo M, Braz CA, Pedrosa C. Políticas de saúde para lésbicas, gays, bissexuais, travestis e transexuais no Brasil: em busca de universalidade, integralidade e equidade. Sex Salud Soc (Rio J.) 2011; (9):7-28.

12. Palma DM, Orcasita LT. Considerations for the design of human immunodeficiency virus (HIV) prevention programs for lesbian and bisexual women. Interface (Botucatu) 2017; 21:1031-8.

13. Pinto VM, Tancredi MV, Tancredi Neto A, Buchalla CM. Sexually transmitted disease/HIV risk behaviour among women who have sex with women. AIDS 2005;19 Suppl 4:S64-9.

14. Sousa JC, Mallmann DG, Galindo Neto NM, Freitas NO, Vasconcelos EMR, Araújo EC, et al. Health promotion of lesbian woman: nursing care. Rev Gaúch Enferm 2014; 35:108-13.

15. Sekoni AO, Gale NK, Manga-Atangana B, Bhadhuri A, Jolly K. The effects of educational curricula and training on LGBT-specific health issues for healthcare students and professionals: a mixed-method systematic review. J Int AIDS Soc 2017; 20:21624.

16. Knight DA, Jarrett D. Preventive health care for women who have sex with women. Am Fam Physician 2017; 95:314-21.

17. Evans AL, Scally AJ, Wellard SJ, Wilson JD, Evans A. Prevalence of bacterial vaginosis in lesbians and heterosexual women in a community setting. Sex Transm Infect 2007; 83:470-5.

18. Berger BJ, Kolton S, Zenilman JM, Cummings MC, Feldman J, McCormack WM. Bacterial vaginosis in lesbians: a sexually transmitted disease. Clin Infect Dis 1995; 21:1402-5.

19. Marrazzo JM, Koutsky LA, Eschenbach DA, Agnew K, Stine K, Hillier SL. Characterization of vaginal flora and bacterial vaginosis in women who have sex with women. J Infect Dis 2002; 185:1307-13.

20. Bostwick WB, Hughes TL, Everett B. Health behavior, status, and outcomes among a community-based sample of lesbian and bisexual women. LGBT Health 2015; 2:121-6.

21. Branstetter AJ, McRee A-L, Reiter PL. Correlates of human papillomavirus infection among a national sample of sexual minority women. J Womens Health (Larchmt) 2017; 26:1004-11.

22. Estrich CG, Gratzer B, Hotton AL. Differences in sexual health, risk behaviors, and substance use among women by sexual identity: Chicago, 2009-2011. Sex Transm Dis 2014; 41:194-9.

23. Lindley LL, Barnett CL, Brandt HM, Hardin JW, Burcin M. STDs among sexually active female college students: does sexual orientation make a difference? Perspect Sex Reprod Health 2008; 40:212-7.

24. Moher D, Liberati A, Tetzlaff J, Altman DG. Preferred reporting items for systematic reviews and meta-analyses: the PRISMA Statement. PLoS Med 2009; 6:e1000097.
25. Massad LS, Xianhong X, Minkoff H, Darragh TM, D'Souza G, Sanchez-Keeland L, et al. Abnormal pap tests and human papillomavirus infections among HIV infected and uninfected women who have sex with women. J Low Genit Tract Dis 2014; 18:50-6.

26. Bailey JV, Farquhar C, Owen C. Bacterial vaginosis in lesbians and bisexual women. Sex Transm Dis 2004; 31:691-4.

27. Bailey JV, Farquhar C, Owen C, Mangtani P. Sexually transmitted infections in women who have sex with women. Sex Transm Infect 2004; 80:244-6.

28. Logie CH, Navia D, Loutfy MR. Correlates of a lifetime history of sexually transmitted infections among women who have sex with women in Toronto, Canada: results from a crosssectional internet-based survey. Sex Transm Infect 2015; 91:278-83.

29. Marrazzo JM, Koutsky LA, Stine KL, Kuypers JM, Grubert TA, Galloway DA, et al. Genital human papillomavirus infection in women who have sex with women. J Infect Dis 1998; 178:1604-9.

30. Sandfort TGM, Baumann LRM, Matebeni Z, Reddy V, Southey-Swartz I. Forced sexual experiences as risk factor for self-reported HIV infection among Southern African lesbian and bisexual women. PLoS One 2013; 8:24-9.

31. Muzny CA, Austin EL, Harbison HS, Hook EW. Sexual partnership characteristics of African American women who have sex with women: impact on sexually transmitted infection risk. Sex Transm Dis 2014; 41:611-7.

32. Tao G. Sexual orientation and related viral sexually transmitted disease rates among US women aged 15 to 44 years. Am J Public Health 2008; 98:1007-9.

33. Secretaria de Vigilância em Saúde, Ministério da Saúde. Protocolo clínico e diretrizes terapêuticas para atenção integral às pessoas com infecções sexualmente transmissíveis. Brasília: Ministério da Saúde; 2015.

34. Muzny CA, Sunesara IR, Austin EL, Mena LA, Schwebke JR. Bacterial vaginosis among African American women who have sex with women. Sex Transm Dis 2013; 40:751-5.

35. Newman L, Rowley J, Vander Hoorn S, Wijesooriya NS, Unemo M, Low N, et al. Global estimates of the prevalence and incidence of four curable sexually transmitted infections in 2012 based on systematic review and global reporting. PLoS One 2015; 10:e0143304.

36. Ma X, Wang Q, Ong JJ, Fairley CK, Su S, Peng $P$, et al. Prevalence of human papillomavirus by geographical regions, sexual orientation and HIV status in China: a systematic review and meta-analysis. Sex Transm Infect 2018; 94:434-42.

37. Anderson L, O’Rorke M, Jamison J, Wilson R, Gavin A; HPV Working Groups Members. Prevalence of human papillomavirus in women attending cervical screening in the UK and Ireland: new data from northern Ireland and a systematic review and meta-analysis. J Med Virol 2013; 85:295-308. 
38. Sabeena S, Bhat PV, Kamath V, Bhat SK, Nair $\mathrm{S}, \mathrm{N}$ R, et al. Community-based prevalence of genital human papilloma virus (HPV) infection: a systematic review and meta-analysis. Asian Pac J Cancer Prev 2017; 18:145-54.

39. Oliveira FA, Pfleger V, Lang K, Heukelbach J, Miralles I, Fraga F, et al. Sexually transmitted infections, bacterial vaginosis, and candidiasis in women of reproductive age in rural Northeast Brazil: a population-based study. Mem Inst Oswaldo Cruz 2007; 102:751-6.

40. Marconi C, Duarte MTC, Silva DC, Silva MG. Prevalence of and risk factors for bacterial vaginosis among women of reproductive age attending cervical screening in southeastern Brazil. Int J Gynecol Obstet 2015; 131:137-41.

41. Chan SK, Thornton LR, Chronister KJ, Meyer J, Wolverton M, Johnson CK, et al. Likely female-to-female sexual transmission of HIV Texas, 2012. MMWR Morb Mortal Wkly Rep 2014; 63:209-12.

42. Baptiste-Roberts K, Oranuba E, Werts N, Edwards LV. Addressing health care disparities among sexual minorities. Obstet Gynecol Clin North Am 2017; 44:71-80.

43. Jones CJ, Schiffman MH, Kurman R, Jacob P, Benowitz NL. Elevated nicotine levels in cervical lavages from passive smokers. Am J Public Health 1991; 81:378-9.

44. Brotman RM, He X, Gajer P, Fadrosh D, Sharma E, Mongodin EF, et al. Association between cigarette smoking and the vaginal microbiota: a pilot study. BMC Infect Dis 2014; 14:471.

45. Muzny CA, Kapil R, Austin EL, Brown L, Hook EW, Geisler WM. Chlamydia trachomatis infection in African American women who exclusively have sex with women. Int J STD AIDS 2016; 27:978-83.

46. Brooks H, Llewellyn CD, Nadarzynski T, Pelloso FC, De Souza Guilherme F, Pollard A, et al. Sexual orientation disclosure in health care: a systematic review. Br J Gen Pract 2018; 68:e187-96.

47. American College of Obstetricians and Gynecologists. Health care for lesbians and bisexual women. Washington DC: American College of Obstetricians and Gynecologists; 2012. (Committee Opinion, 525).

48. Reisner SL, Mimiaga MJ, Case P, Grasso C, O’Brien CT, Harigopal P, et al. Sexually transmitted disease (STD) diagnoses and mental health disparities among women who have sex with women screened at an Urban Community Health Center, Boston, MA, 2007. Sex Transm Dis 2010; 37:5-12.

49. Richters J, Prestage G, Schneider K, Clayton S. Do women use dental dams? Safer sex practices of lesbians and other women who have sex with women. Sex Health 2010; 7:165-9.

50. Rowen TS, Breyer BN, Lin T-C, Li C-S, Robertson PA, Shindel AW. Use of barrier protection for sexual activity among women who have sex with women. Int J Gynecol Obstet 2013; 120:42-5
51. Schick V, Rosenberger JG, Herbenick D, Reece M. Sexual behaviour and risk reduction strategies among a multinational sample of women who have sex with women. Sex Transm Infect 2012; 88:407-12.

52. Marrazzo JM, Thomas KK, Ringwood K. A behavioural intervention to reduce persistence of bacterial vaginosis among women who report sex with women: results of a randomised trial. Sex Transm Infect 2011; 87:399-405.

53. Logie CH, Lacombe-Duncan A, Weaver J, Navia $D$, Este D. A pilot study of a group-based HIV and STI prevention intervention for lesbian, bisexual, queer, and other women who have sex with women in Canada. AIDS Patient Care STDS 2015; 29:321-8.

54. White W, Brenman S, Paradis E, Goldsmith ES, Lunn MR, Obedin-Maliver J, et al. Lesbian, gay, bisexual, and transgender patient care: medical students' preparedness and comfort. Teach Learn Med 2015; 27:254-63.

55. Müller A. Teaching lesbian, gay, bisexual and transgender health in a South African health sciences faculty: addressing the gap. BMC Med Educ 2013; 13:174.

56. Solotke M, Sitkin NA, Schwartz ML, Encandela JA. Twelve tips for incorporating and teaching sexual and gender minority health in medical school curricula. Med Teach 2017; Epub ahead of print.

57. Forcey DS, Walker SM, Vodstrcil LA, Fairley CK, Bilardi JE, Law M, et al. Factors associated with participation and attrition in a longitudinal study of bacterial vaginosis in Australian women who have sex with women. PLoS One 2014; 9:e113452.

58. Bauer GR, Welles SL. Beyond assumptions of negligible risk: sexually transmitted diseases and women who have sex with women. Am J Public Health 2001; 91:1282-6.

59. Evans BA, Kell PD, Bond RA, MacRae KD. Racial origin, sexual lifestyle, and genital infection among women attending a genitourinary medicine clinic in London (1992). Sex Transm Infect 1998; 74:45-9.

60. Everett BG. Sexual orientation disparities in sexually transmitted infections: examining the intersection between sexual identity and sexual behavior. Arch Sex Behav 2013; 42:225-36.

61. McCaffrey M, Varney P, Evans B, TaylorRobinson D. Bacterial vaginosis in lesbians: evidence for lack of sexual transmission. Int J STD AIDS 1999; 10:305-8.

62. Muzny CA, Sunesara IR, Martin DH, Mena LA. Sexually transmitted infections and risk behaviors among African American women who have sex with women: does sex with men make a difference? Sex Transm Dis 2011; 38:1118-25.

63. Xu F, Sternberg MR, Markowitz LE. Women who have sex with women in the United States: prevalence, sexual behavior and prevalence of herpes simplex virus type 2 infection. Sex Transm Dis 2010; 37:407-13. 


\section{Resumo}

Nosso objetivo foi revisar sistematicamente dados sobre o risco de infecções sexualmente transmissiveis (ISTs) e vaginose bacteriana em mulheres lésbicas e sugerir estratégias para melhorar prevenção, diagnóstico e tratamento. Uma estratégia de busca para lésbica, ISTs e vaginose bacteriana foi aplicada às bases PubMed, LILACS e BDENF. De 387 referências únicas identificadas, 22 preenchiam os critérios de inclusão (estudos seccionais relatando a prevalência de 8 ISTs/vaginose bacteriana e histórico de ISTS). A infecção mais frequentemente relatada foi vaginose bacteriana $e$ nenhum estudo relatou dados sobre hepatite $B$. Uma ampla gama de prevalências foi observada para a maioria das infecções. Em termos de fatores de risco, o número de parceiras sexuais, ser ou ter sido fumante, histórico de sexo forçado e estigma sexual parecem aumentar o risco de ISTs e vaginose bacteriana. Os resultados desta revisão são discutidos à luz de diretrizes que abordam diretamente a saúde da comunidade LGBT e também de estudos relevantes que investigaram tanto práticas de sexo seguro quanto a complexa relação entre pessoas LGBT e profissionais de saúde. Um conjunto de recomendações para melhorar o cuidado preventivo para mulheres lésbicas é proposto. É razoável afirmar que pouco se sabe sobre a dimensão da transmissão de ISTs e vaginose bacteriana em atividades sexuais entre mulheres ou sobre os fatores de risco para ISTs e vaginose bacteriana em mulheres lésbicas. De fato, a qualidade dos estudos foi, de forma geral, baixa ou muito baixa, com incerteza significativa quanto a seus resultados. Contudo, consideramos que o conhecimento disponivel indica alguns caminhos a serem seguidos por profissionais de saúde e na elaboração de politicas públicas para melhorar ações em direção a uma melhor saúde sexual de mulheres lésbicas.

Doenças Sexualmente Transmissíveis; Vaginose Bacteriana; Homossexualidade Feminina; Politica de Saúde

\section{Resumen}

Nuestro objetivo fue realizar una revisión sistemática de los datos sobre infecciones de trasmisión sexual (ITS) y riesgo de vaginosis bacteriana entre mujeres lesbianas y sugerir estrategias para mejorar su prevención, diagnóstico y tratamiento. La estrategia de búsqueda de lesbiana, ITS y vaginosis bacteriana se realizó en las bases de datos de PubMed, LILACS y BDENF. De 387 referencias únicas recogidas, 22 reunían criterios de inclusión (estudios transversales informaron sobre la prevalencia de 8 ITS/vaginosis bacteriana e historial de una ITS). La infección más frecuente fue vaginosis bacteriana y ningún estudio proporcionó datos sobre hepatitis $B$. se observó un amplio rango de prevalencia para la mayoría de las infecciones. En términos de factores de riesgo, el número de parejas sexuales, ser fumador o exfumador, un pasado de abusos sexuales, así como el estigma sexual parece que incrementaron el riesgo de ITS y vaginosis bacteriana. Los hallazgos del presente estudio se discuten a la luz de las directrices de salud directamente dirigidas a la comunidad LGBT, y también a estudios relevantes que investigaban tanto las prácticas sexuales seguras, como la relación intricada entre individuos del colectivo LGBT y sus proveedores de salud. Se propone un conjunto de recomendaciones para mejorar el cuidado preventivo de mujeres lesbianas. Es razonable afirmar que se conoce poco sobre el grado de transmisión de las ITS y vaginosis bacteriana en las relaciones sexuales entre mujeres o sobre los factores de riesgo para las ITS y vaginosis bacteriana entre mujeres lesbianas. De hecho, la calidad general de los estudios fue baja o muy baja con una incertidumbre significativa sobre sus resultados. No obstante, consideramos que el conocimiento disponible indica algunos caminos que pueden recorrer proveedores de salud y tomadores decisiones para mejorar sus acciones orientadas a una mejor salud sexual de las mujeres lesbianas.

Enfermedades de Transmisión Sexual; Vaginosis

Bacteriana; Homosexualidad Femenina;

Politica de Salud
Submitted on 14/Jun/2018

Final version resubmitted on 30/Nov/2018

Approved on 11/Jan/2019 